ORL 1989;51:I-VI

\title{
Contents, Vol. 51, 1989
}

\section{No. 1 Original Paper}

Turnover of Sulphur Compounds in the Endolymphatic Sac: An Autoradiographic Study in the Mongolian Gerbil

Barbara, M.; Takumida, M.; Nilsson, J.; Bagger-Sjöbäck, D.; Rask-Andersen, H. . . . 1

Assessment of Head Shaking Test in Neuro-Otological Practice

Vicini, C; Casani, A.; Ghilardi, P 8

Automatic Electronystagmus Analysis and Documentation: Recent Advances in the Study of Vestibular, Optokinetic and Pursuit Tracking Function (with 3 color plates)

Allum, J.H.J.; Honegger, F.; Ura, M.; Pfaltz, C.R 14

Late Results of Surgery in Different Cholesteatoma Types

Tos, M.; Lau, T 33

Bacterial Flora in the Nasopharynx and Nasal Cavity of Healthy Young Men

Ylikoski, J.; Savolainen, S.; Jousimies-Somer, H 50

Juvenile Angiofibromas: A 40-Year Surgical Experience

Amedee, R.; Klaeyle, D.; Mann, W.; Geyer, H 56

Repeat Mediastinoscopy

Puhakka, H.J 62

Book Review 67

Announcements 68

No. 2 Original Paper

Epstein-Barr Virus (EBV) Infection by Cocultivation of Fibroblast-Dominant Cell Line and EBV-Transformed Lymphocytes

Furukawa, M.; Kamide, M.; Miwa, T.; Sakumoto, M.; Umeda, R 69

Spontaneous Lymphoblastoid Transformation of Cells Obtained from Human Tonsils

Takimoto, T.; Tanaka, S.; Masuda, K.; Umeda, R 77

Preparation of Human Temporal Bone for Immunohistochemical Investigation

(with 1 color plate)

Altermatt, H.J.; Gebbers, J.-O.; Arnold, W.; Kraft, R.; Laissue, J.A 83

IV

Contents

Gas Permeability of Round Window Membrane

Sasa, H.; Nagahara, K. Yamashita, T.; Kumazawa, T 88

Hydrocortisone Applied into the Round Window Niche Causes Electrophysiological Dys function on the Inner Ear

Spandow, O.; Anniko, M.; Hellström, S

Functional Changes in the Inner Ear in Renal Insufficiency. An Experimental Study in the Rat

Anniko, ML; Hellström, S 103 
Human Otoconial Crystal Growth. An Approach from Morphological and Morphometric

Data

Sánchez-Fernández, J.M.; Rivera-Pomar, J.M.; Tello, M.J 108

Synthesis of Glycocalyx and Associated Structures in Vestibular Sensory Cells

Takumida, M.; Wersäll, J.; Bagger-Sjöbäck, D.; Harada, Y 116

Lack of Differentiation of the Isolated Murine Statoacoustic Ganglion during Organ Cul ture

Berggren, D.; Anniko, M 124

Microcomputer Programs for Video Stimulation of Eye Movements

Huygen, P.L.M.; Huygen, L.J.M.; Nicolasen, M.G.M 130

Book Review 135

Announcements 136

No. 3 Original Paper

Glycocalyx and Ciliary Interconnections of the Vestibular End Organs: An Investigation by

High-Resolution Scanning Electron Microscopy

Takumida, M 137

Carbohydrates of the Vestibular End Organs Detected by Lectins

Takumida, M.; Urquiza, R.; Bagger-Sjöbäck, D.; Wersäll, J 144

Effects of Ethyl Alcohol and Heavy-Water Administration on Vestibulo-Ocular Reflex in

Rabbits

Koizuka, I.; Takeda, N.; Kubo, T,; Matsunaga, T.; Cha, C.I 151

Change in K+ Activity of the Scala Media Produced by Vasopressin

Shugyo, A.; Mori, N.; Matsunaga, T 156

Benign Paroxysmal Vertigo of the Horizontal Canal

Pagnini, P.; Nuti, D.; Vannucchi, P 161

Natural Allergen Exposure Does Not Influence the Density of Goblet Cells in the Nasal

Mucosa of Patients with Seasonal Allergic Rhinitis

Karlsson, G.; Pipkorn, U 171

The Bacteriology of Acute Maxillary Sinusitis

Ylikoski, J.; Savolainen, S.; Jousimies-Somer, H 175

Chondroma of the Tongue

Ishibashi, T.; Nomura, Y.; Kojimabara, M 182

Vascular Leiomyoma of the Parotid Gland

Kido, T.; Sekitani, T 187

Mediastinoscopy: Not Needed Preoperatively in CT-Negative Lung Carcinoma?

Liippo, K.; Puhakka, H.; Katevuo, K.; Reunanen, K.; Vänttinen, E 192

Book Reviews 196

Allum/Honegger/Ura/Pfaltz

Plate I

HNO Unive $\Gamma$ sitaetsklinik

Patienten N $\gamma$. : 786 Datum : 08.01.88

Kantonsspital Basel

Unte $\Gamma$ suchungs $\mathrm{N} \gamma$. : 1 Identifikation : 12/86 


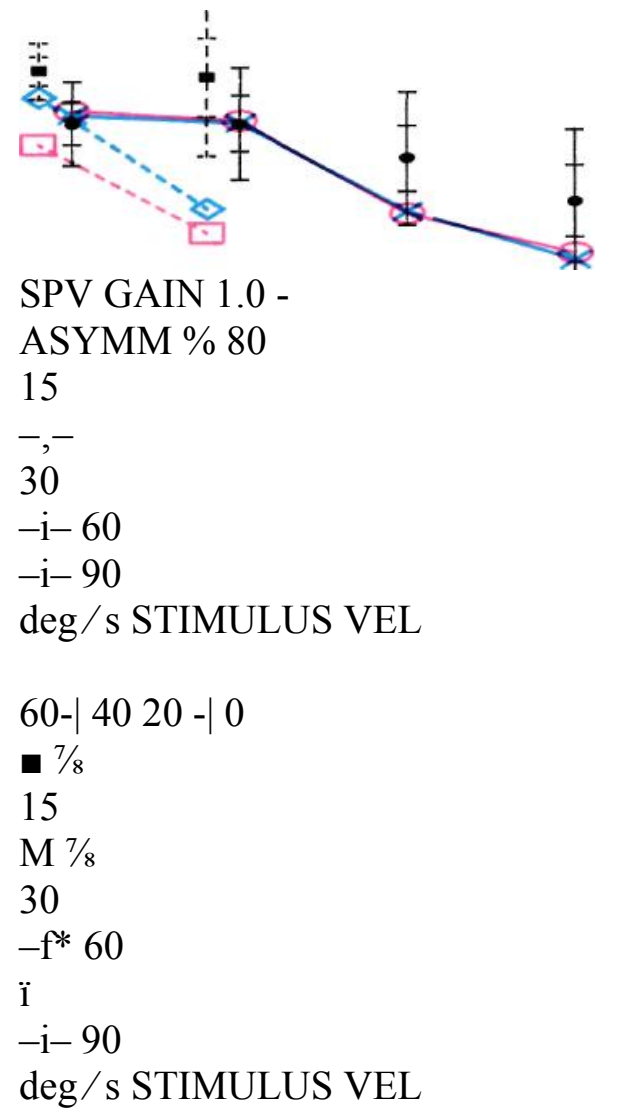

ORL, Vol. 51

S. Karger, Basel

Fig. 1. Haematoxylin-eosin stained basal cell carcinoma. The typical palisade-like formation of the clumps of basal cell carcinoma cells as well as the individual proliferating cells (arrows) can be seen. $\times 625$.

Fig. 2. Frozen section of basal cell carcinoma stained with 9-aminoacridine. Cells possessing yellow fluorescence contain active GB, this section was taken from the same patient as the section presented in figure $1 . \times 1,000$.

Fig. 3. Frozen section of basal cell carcinoma stained with 9-aminoacridine. Individual proliferating tumour cells clearly show yellow fluorescent ring-staining with dark nuclear regions. $\times 1,000$.

Fig. 4. Frozen section of basal cell carcinoma treated with liver extract followed by 9aminoacrid-ine staining. Prolonged exposure was required for this photograph due to the virtual absence of 9-arrtino-acridine bound to the tumour cells. As a result a general pale yellow print was obtained in which even the muscle cells which lack GB appear pale yellow. Tumour cells are indicated by arrows. $\times 750$.

Allum/Honegger/Ura/Pfaltz

Plate II

HNO Univ $\beta \Gamma$ sitaetsklinik

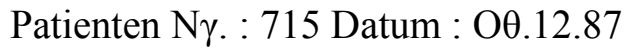

Kantonsspital Base] 
Untersuchungs $\mathrm{N} \gamma$. : 1 Identifikation : 644/87

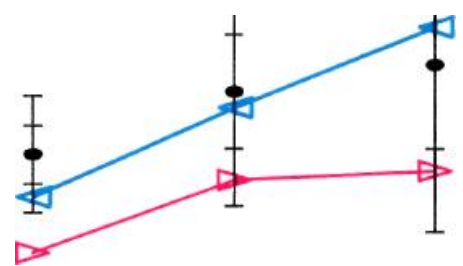

SPV GAIN 0.8 -,

0.60 .40 .2

0

20

$-1-40$

$\operatorname{deg} / \mathrm{s} 2$

TIME CONST 30 sees

20

10

ASYMM \%

20

40

deg I s2

ORL, Vol. 51

S. Karger, Basel

Plate III

Allum/Honegger/Ura/Pfaltz

HORIZ VOR RESULTS KBS-OTONEUROLOGIE

Patient

Gebur > tsdatum : 03.03.27 Alter : 61 JAHRE 5 MONATE

HNO Universítaetsklinik

Patienten N $\gamma$. : 715 Datum : 10.08 .88

Kantonsspital Basel

Unte $\Gamma$ suchungs $N \gamma$. : 2 Identifikation : 320/88

SPV GAIN 0.8

TIME CONST 1 - 30 sees

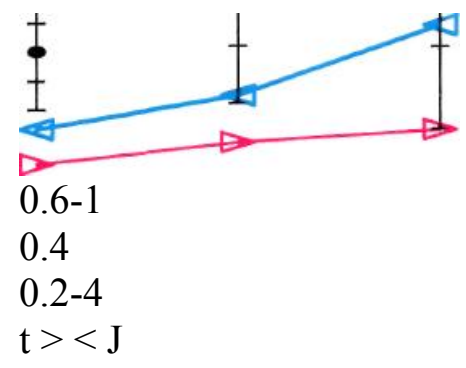


$-1-20$

40

$\mathrm{deg} / \mathrm{s} 2$

L- 0

ASYMM \%

20

40

$\mathrm{deg} / \mathrm{s} 2$

ORL, Vol. 51

S. Karger, Basel

Contents

$\mathrm{V}$

No. 4 Original Paper

Postoperative Active-Specific Immunotherapy of Lymph Node Micrometastasis in a

Guinea Pig Tumor Model

Bier, H.; Armonat, G.; Bier, J.; Schirrmacher, V.; Ganzer, U

Laryngeal Pathologies Observed in Microlaryngoscopy

Lehmann, W.; Pampurik, J.; Guyot, J.-P 206

Cytopathology in Cancer of Larynx

Gaafar, H.; Hussein, M.; El-Assi, H 216

Localization of the Integral Membrane Glycoprotein Synaptophysin and the Surface

Glycoprotein Egp-34 in the Embryonic and Adult Human Inner Ear

Anniko, M.; Arnold, W.; Thornell, L.E 221

Further Clinical Experiences with Middle-Ear Implantable Hearing Aids: Indications and

Sound Quality Evaluation

Suzuki, J.-L; Kodera, K.; Suzuki, M.; Ashikawa, H 229

Clinical Significance of SP/AP Ratio in Inner Ear Diseases

Ohashi, T.; Takeyama, $1 \quad 235$

Acoustic Trauma-Induced Ménière's Syndrome

Roitman, R.; Talmi, Y.P.; Finkelstein, Y.; Silver, S.; Sadov, R.; Zohar, Y 246

Case Report

Ramsey-Hunt Syndrome in a Preschool Infant

Bjerkhoel, A.; Hydén, D 251

Book Reviews 255

Announcements 256

No. 5 Original Paper

Characteristics of Epstein-Barr Virus-Carrying Lymphoblastoid Cells Derived from Human

Tonsil: EBV Production and Autoantibody Response

Takimoto, T.; Tanaka, S.; Ishikawa, S.; Masuda, K.; Umeda, R 257

Transitional Papilloma of the Nasal Cavity and Paranasal Sinuses. Clinical Course, Viral Etiology and Malignant Transformation 
Siivonen, L.; Virolainen, E 262

Immunological Abnormality of the Serological Tests in Bilateral Sensorineural Hearing Loss

Ikeda, K.; Kobayashi, T.; Itoh, Z.; Suzuki, H.; Kusakari, J.; Takasaka, T 268

Effect of Acetazolamide (Diamox ${ }^{\circledR}$ ) on the Endolymphatic Sac

Takumida, M.; Bagger-Sjöbäck, D.; Rask-Andersen, H 276

Frequency-Specific Auditory Brainstem Response Analysis of Young Normal, Aged Normal and Aged Alcohol-Addicted Rats

Anniko, M.; Hellström, S.; Wahlström, G 285

Microprobe Analysis of Cryofixed, Chemically Untreated Freeze-Dried Cochlear Hair Cells

Anniko, M.; Wróblewski, R 290

Surgical Management of Labyrinthine Fistulae in Chronic Otitis Media with Cholestea-

toma by a One-Stage Closed Technique

Ostri, B.; Bak-Pedersen, K 295

Efficacy of Oral Oxpentifylline in the Management of Idiopathic Tinnitus

Salama, N.Y.; Bhatia, P.; Robb, P.J 300

Contents

Recovery of Gaze Disturbance in Bilateral Labyrinthine Loss

Takahashi, M.; Saito, A.; Okada, Y.; Yoshida, A 305

Evaluation of a New 'Anti-Snoring Device'

Jönsson, A.; Strom, T.; Hedner, J.; Ejnell, H 311

Case Report

Development of Significant Sternoclavicular Joint Hypertrophy Following Radical Neck

Dissection

Takimoto, T.; Ishikawa, S.; Tanaka, S.; Masuda, K.; Umeda, R 317

Short Communication

Structural Basis for an Isometric Contraction of Human Outer Hair Cells

Arnold, W.; Anniko, M 321

Announcements 294,320

Original Paper

Histogenetic Study of the Vestibular Ganglion in the Developing Chick Embryo by Lect $1 / 8$

Horseradish Peroxidase Methods

Yamashita, H.; Sekitani, T 325

Brainstem Auditory Evoked Response Sensitivity: Camparison with Other Neurologic

Tests in the Detection of Retrocochlear Lesions

Benitez, J.T.; Arsenault, M.D 332

Supporting and Membrane Structures of Human Outer Hair Cells: Evidence for an Isometric

Contraction

Arnold, W.; Anniko, M 339

Effect of Terbutaline on Human Eustachian Tube Function

White, P.; Malm, L.; Tjernström, Ö 354

Activity of the Proteolytic Enzyme Guanidinobenzoatase in Human Basal Cell Carcinoma

(with 1 colour plate)

Steven, F.S.; Maier, H.; Born, A.; Weidauer, H 360

Malignant Fibrous Histiocytoma Arising from the Vocal Cord

Masuda, K.; Takimoto, T.; Yoshizaki, T.; Sakano, K.; Umeda, R 365 
Case Report

Mesenchymal Chondrosarcoma of the Ethmoid Sinus

Takimoto, T.; Kato, H.; Yamashima, T.; Yamashita, J.; Umeda, R 369

Announcement

375

Author Index 376

Subject Index 377 